Vol.45, Special n. : pp. 143-149, September 2002 ISSN 1516-8913 Printed in Brazil

\title{
Drug Interaction with Radiopharmaceuticals: Effect on the Labeling of Red Blood Cells with Technetium-99m and on the Bioavailability of Radiopharmaceuticals
}

\author{
Maria Luisa Gomes ${ }^{1}$; Marcia B. Nunes de Oliveira ${ }^{1}$ and Mario Bernardo-Filho ${ }^{1,2 *}$ \\ ${ }^{I}$ Universidade do Estado do Rio de Janeiro, Instituto de Biologia Roberto Alcantara Gomes, Departamento de \\ Biofísica e Biometria, Av. 28 de setembro, 87, 20551-030, Rio de Janeiro - RJ - Brasil. ${ }^{2}$ Instituto Nacional do \\ Câncer, Coordenadoria de Pesquisa, Praça Cruz Vermelha 23, 20230-130, Rio de Janeiro - RJ - Brasil
}

\begin{abstract}
The evidence that natural and synthetic drugs can affect radiolabeling or bioavailability of radiopharmaceuticals in setting of nuclear medicine clinic is already known. However, this drug interaction with radiopharmaceuticals (DIR) is not completely understood. Several authors have described the effect of drugs on the labeling of blood elements with technetium-99m $(99 \mathrm{mTc})$ and on the biodistribution of radiopharmaceuticals. When the DIR is known, if desirable or undesirable, the natural consequence is a correct diagnosis. However, when it is unknown, it is undesirable and the consequences are the possibility of misdiagnosis and/or the repetition of the examination with an increase of radiation dose to the patient. The possible explanation to the appearance of DIR are (a) radiopharmaceutical modification, (b) alteration of the labeling efficiency of the radiopharmaceutical, (c) modification of the target, (d) modification of no target and/or the (e) alteration of the binding of the radiopharmaceutical on the blood proteins. The effect of drugs on the labeling of blood elements with $99 \mathrm{mTc}$ might be explained by (i) a direct inhibition (chelating action) of the stannous and pertechnetate ions, (ii) damage induced in the plasma membrane, (iii) competition of the cited ions for the same binding sites, (iv) possible generation of reactive oxygen species that could oxidize the stannous ion and/or (v) direct oxidation of the stannous ion. In conclusion, the development of biological models to study the DIR is highly relevant.
\end{abstract}

Key words: Drug interaction, blood elements, radiopharmaceuticals, bioavailability

\section{INTRODUCTION}

In nuclear medicine, radioactive tracers, called radiopharmaceuticals, are employed in the study of blood flow, metabolism, morphology of an organ. (Carlsson, 1995; Chandra, 1998) and to evaluate the drug formulation and drug delivery systems (Perkins and Frier, 1999). Unexpected patterns of radiopharmaceutical biodistribution can be associated with a disease. However many factors, including drug therapy, radiation therapy besides pathological process could affect the biodistribution of the radiopharmaceutical. Passos et al., 2000 and Passos et al., 2002 have demonstrated that the dietary conditions can also interfere with the biodistribution of radiopharmaceutical. Some authors have desc ribed that synthetic or natural products in the blood, as well as, the labeling conditions can have an effect on the labeling of red blood cells with technetium -

\footnotetext{
* Author for correspondence
} 
99m (99mTc) (Sampson, 1993; Hojelse et al., 1994; Sampson 1996; Braga et al., 2000). It has already reported that the biodistribution of radiopharmaceuticals used in diagnostic imaging in nuclear medicine is also altered by drugs (Hladik et al., 1982; Hladik et al., 1987; Hesslewood and Leung, 1994; Gomes et al., 2002). The drug interaction with radiopharmaceuticals (DIR) can be know or unknown (Owunwanne et al., 1995).

Blood cells elements labeled with $99 \mathrm{mTc}$ has come into wide use in clinical nuclear medicine for several important applications, including imaging of the cardiovascular system, detection of gastrointestinal hemorrhage and localization of intramuscular hemangioma (Chandra, 1998, Harbert et al., 1996, Early and Sodee, 1996). Red blood cells (RBC) labeling with $99 \mathrm{mTc}$ can be done by a completely in vitro technique, by in vivo methods, or by a combination of these two, called in vitro/in vivo labeling. The labeling of blood elements with $99 \mathrm{mTc}$ needs a reducing agent and the stannous ions are frequently used (Bernardo Filho et al., 1983, Harbert et al., 1996, Saha, 1998).

\section{Drug interaction and the labeling of blood elements}

Various authors have studied the effect of different drugs (natural and synthetic) on the labeling of blood elements with radionuclides and have reported important findings (Bernardo-Filho et al., 1994, Sampson, 1996, Braga et al., 2000, Spicer et al., 1999). The mechanism of the fixation of the radionuclide on the blood elements have also been studied (Bernardo-Filho, 1986, Srivastava et al., 1984; Callahan and Rabito, 1990; Bernardo-Filho et al., 1994)

In a review, Sampson, 1996, had reported that that hydralazine and methyldopa significantly decrease the labeling efficiency of blood cells, possibly through oxidation of the stannous ion present in the kit. He had also reported that other workers have shown that if clinical doses of propanolol, verapamil, chlorothiazide or frusemide are incubated with red blood cells, a significant reduction in the labeling efficiency is observed. Calcium channel blockers have implicated in unusual and interesting effects in nuclear medicine. These include increased uptake of iodine-131-meta-iodo-benzyl guanidine $\quad{ }^{131} \mathrm{I}-$ MIBG) into tumors. It is possible that nifedipine and other calcium channel antagonist's block the uptake of stannous ion into the red cells, thus preventing proper uptake by the tracer. Sulphasalazine therapy is well established as a cause of haemolysis in patients with inflammatory bowel disease. Cephalosporins have been reported to interfere seriously with the chemistry of the red cell membrane. Other drugs listed as disrupt ing red cell function include cytostatics, neuroleptics, tricyclic antidepressants, omeoprazole and quinine. It is well known that the concentration of stannous ion may have a marked effect on the in vitro labeling efficiency of red cells, and it has been shown that optimum yields are achieved with concentrations of $0.03-0.15 \mathrm{mg}$ ion per milliliter of blood. Any deviation from this range is likely to cause a decrease in labeling efficiency of up to $20 \%$. The same group of workers also showed that propanolol, verapamil, chlorothiazide and frusemide all produced quite significant decreases in labeling efficiency when incubated with red cells.

Lee et al., 1983, have studied the effect of two antihypertensive agents (captopril and prazosin) and of digoxin on the efficiency of 99mTc binding to RBCs of the rat. RBCs were labeled with $99 \mathrm{mTc}$ in vivo. The findings demonstrated a significant reduction of RBC tagging with $99 \mathrm{mTc}$ in rats treated with prazosin and digoxin but not with captopril. The data suggest a potential interference by patient medication with the performance of blood-pool studies. It was thought that the adverse effect with digoxin was associated with an alteration in red cell membrane transport of the tracer due to inhibition of the sodium potassium/ATP-ase dependent pump.

Cyclosporin has been mentioned earlier in connection with problems of white cell labeling. The same drug also affects red cells, shown that the labeling efficiency had decreased (Hesslewood and Leung, 1994). Later work revealed that the drug effect was influenced by the amount of stannous ion in the kit, and that if the kit was changed to containing higher levels of tin, the problem disappeared (Hladik et al., 1987).

An interesting observation made by Tatum et al, 1983 was that blood from patients who had previously received iodinated contrast media demonstrated a sub-optimal red cell labeling efficiency. Mean labeling efficiency decrease from 90 to $30 \%$, supposedly as a result of interference with the redox potential of the stannous ion. The authors recommended that studies employing 
99mTc-RBC labeling using this technique be performed prior to administration of iodinated contrast media. Moreover, this effect should be kept in mind in gastrointestinal bleeding studies performed using $99 \mathrm{mTc}-\mathrm{RBC}$, as well as in cardiac imaging studies.

Other factors that can influence labeling efficiency include the clinical condition of the patient and the use of intravenous cannulas containing Teflon. In their series of patients, heparin and chemotherapeutic agents were found to have significant adverse effects. It has been postulated that heparin might compete with the red blood cell for the binding of stannous ion, and chemotherapeutics agents may cause alterations in the erythrocyte membrane. Eising and S ciuk, 1995 obtained satisfactory in vivo labeling in patients receiving chemotherapy and overcame the problems of Teflon cannulas by using a fast injection of the stannous agents followed by a saline flush. Spicer et al., 1999 have demonstrated that some chemotherapeutic drugs do not alter the labeling of red blood cells with $99 \mathrm{mTc}$.

Vento et al., 2000, have reported various drugs capable to contribute to the direct binding of $99 \mathrm{mTc}$-pertechnetate to red blood cells in vivo, as atenolol (a beta-1 blocker), carbamazepine (an anticonvulsant), cellulose fiber, disulfiram (to treat alcoholism), fluoxetine hydrochloride (an antidepressant), lorazepam (an antianxiety and antidepressant), lubricant eyes drops, multivitamins, olanzapine (an antipsychotic), ranitidine (an $\mathrm{H}-2$ antagonist), acetaminophen (for pain), epinephrine autoinject, guanifensin/methorfan (an expectorant, supressant), hydrocortisone cream and oral magnesium/aluminum hydroxides with simethicone (an antigas agent).

The use of medicinal plants or natu ral products has increased in the last decades all over the world. There are some studies about the effect of the medicinal plants on the labeling of blood elements with $99 \mathrm{mTc}$. Some authors have reported that extracts of Thuya occidentalis (Oliveira et al., 1996), Nicotiana tabacum (Vidal et al., 1998), Maytenus ilicifolia (Oliveira et al., 2000), chayotte (Diré et al., 2001), Ginkgo biloba (Moreno et al., 2001) and Paullinia cupana (Oliveira et al., 2002) are capable to modify the binding of $99 \mathrm{mTc}$ on the blood elements. However, extracts of Peumus boldus (Reineger et al., 1999) could aid the labeling of red blood cells with $99 \mathrm{mTc}$ and extracts of cauliflower (Lima et al., 2002) do not modify this labeling.

\section{Drug interaction and the bioavailability of radiopharmaceuticals}

An unexpected patterns of radiopharmaceutical distribution provoke a flurry of inquiries regarding the quality of the administered agent. But, the alterations in biodistribution may be related to the DIR. Hesslewwood and Leung, 1994 have reported that various drugs are capable to alter the biodistribution of different radiopharmaceuticals. Britto et al., 1998 using an animal model, have demonstrated that vincristine increased significantly the uptake of the $99 \mathrm{mTc}-\mathrm{DTPA}$ (diethylenetriaminepentaacetic acid) in thymus, ovary, uterus, spleen, kidneys, heart, stomach, lungs, liver and bone. Vincristine was capable to increase the blood pool of the radioactivity of $\mathrm{Ga}$ 67 citrate (Hladik et al., 1987). Mattos et al., 1999, have verified that vincristine modify the biodistribution of the radiopharmaceutical $99 \mathrm{mTc}$ phytate in Balb/c mice.

Gomes et al., 1998, have also reported that mitomycin-C increased the uptake of $99 \mathrm{mTc}-\mathrm{MDP}$ (methylenediphosphonic acid) in thymus, ovary, uterus, heart, stomach, pancreas, kidneys, spleen and lungs. Gomes et al., 2001 have reported that mitomycin-C is capable to alter the uptake of radiopharmaceuticals used for renal evaluations.

Chen et al., 1994 have reported that due to its nephrotoxicity, gentamicin may cause abnor mal renal uptake to be seen on $99 \mathrm{mTc}-\mathrm{MDP}$ bone scintigraphy and the presence of the radiopharmaceutical in the kidneys, along with an increase in renal retention.

Santos et al., 1995, in in vivo studies have demonstrated that cyclophosphamide is capable to alter the effective half-life of the radiopharmaceuticals $99 \mathrm{mTc}-\mathrm{MDP}$ and $99 \mathrm{mTc}-$ pertechnetate.

Mattos et al., 1999, have studied the effect of a chemotherapeutic drug on the bioavailability of 99mTc-MDP in different organs isolated from animals treated with vincristine and have shown a decrease of the uptake in uterus, ovary, spleen, thymus, lymph nodes (inguinal and mesentheric), kidney, liver, pancreas, stomach, heart, brain and bone. They have also shown that the uptake of 99mTc-PYP (pyrophosphate) decreas ed in spleen, thymus, lymph nodes (inguinal and mesentheric), kidney, lung, liver, pancreas, stomach, heart and 
brain and it increased in bone and thyroid. in the treated animals.

Mattos et al., 2001 have also reported that the uptake of 99mTc-GHA (glucoheptonic acid) decreased in uterus, ovary, spleen, thymus, lymph nodes (inguinal and mesentheric), kidney and heart isolated from animals treated with vincristine.

\section{DISCUSSION}

In the presence of pathophysiologic conditions, due to the changes in the tissues the normal biodistribution and elimination pattern of a radiopharmaceutical may be altered. This altered biologic behavior due to diseases helps a physician to define a diagnosis of a possible disease (Carlsson, 1995). However, this alltered biologic behavior may also be due to interferences caused by pharmacodynamic effects of drugs. When it is undesired, it may be due to toxicity or direct interaction

Due to the importance of the DIR, the study of the models to evaluate this phenomenom is worthwhile. As can be seen in the Figure 1, when the DIR is known, if desirable or undesirable, the natural consequence is a correct diagnosis (diagnostic intervention or drug therapy monitoring). However, when is unknown, it is undesirable and the consequences are the possibility of misdiagnosis (misleading information that can either mask or mimic certain disease symptoms) and/or the repetition of the examination with an increase of radiation dose to the patient. There are possible explanation to the appearance of DIR, as radiopharmaceutical modification, alteration of the labeling efficiency, modification of the target, modification of no target and the alteration of the binding of the radiopharmaceutical on the blood proteins. (Hesslewood and Leung, 1994; Owunwann e et al., 1995; Hung et al., 1996; Owunwanne et al., 1998).

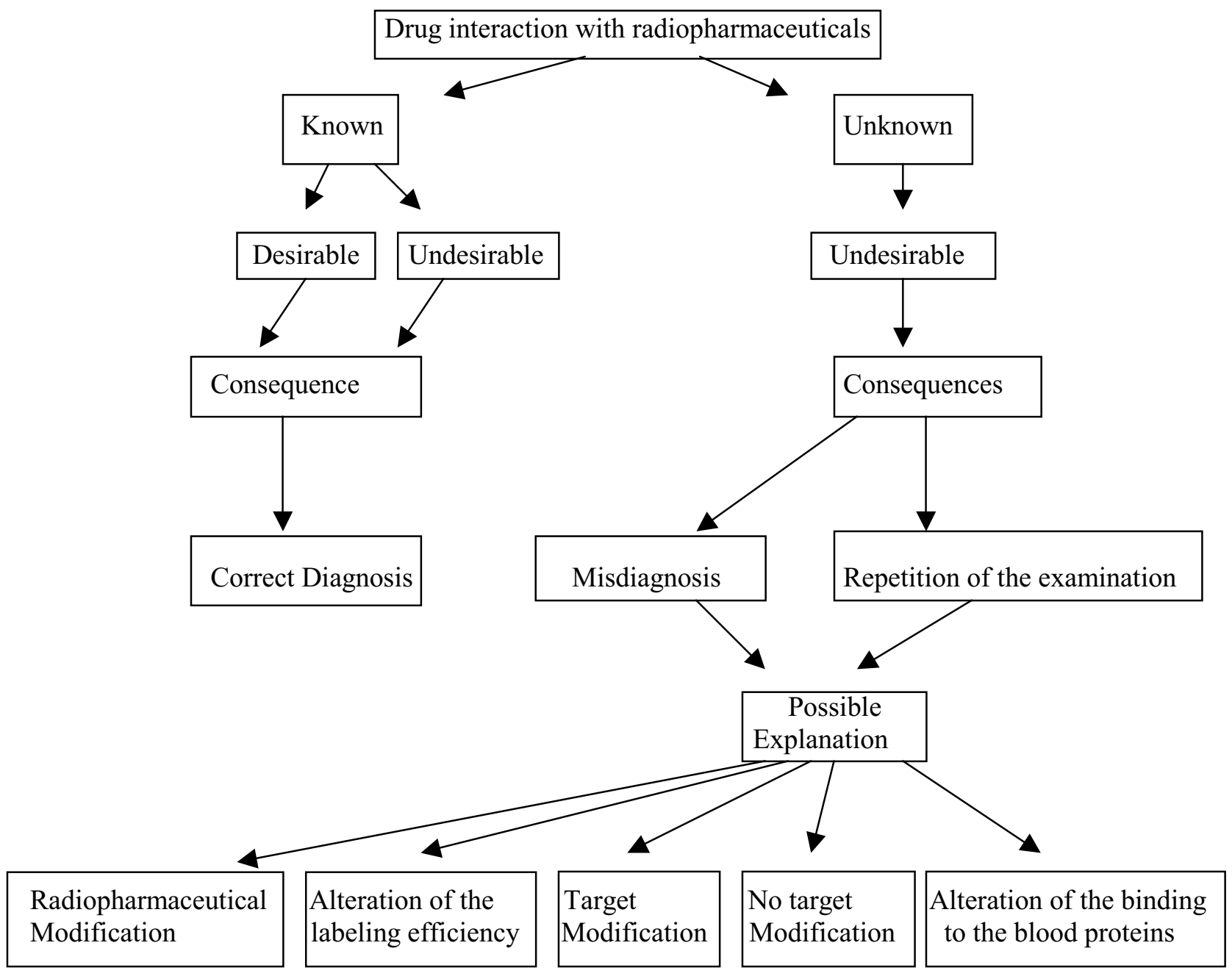

Figure 1 - Possible pathways to evaluate the drug interaction with radiopharmaceuticals 
Concerning to the labeling of blood elements with $99 \mathrm{mTc}$, the exact mechanism of the effect of natural and synthetic substances on the labeling of red blood cells is not completely established. However, it might be explained (i) by a direct inhibition (chelating action) of the referred ions, (ii) by damage induced in the pla sma membrane, (iii) by competition of the cited ions for the same binding sites, (iv) by possible generation of reactive oxygen species that could oxidize the stannous ion and/or (v) by direct oxidation of the stannous ion.

In conclusion, the knowledge abo ut the DIR is very important to secure and safe diagnosis and the development of biological models to study this phenomenon is highly relevant and desired.

\section{ACKNOWLEDGMENTS}

The authors thank FAPERJ, CNPq and UERJ for the support.

\section{RESUMO}

A evidência de que drogas naturais ou sintéticas podem afetar a radiomarcação ou a biodisponibilidade de radiofármacos nos procedimentos de medicina nuclear já é bem conhecida. Entretanto, essa interação de droga com radiofármacos (IDR) não está completamente compreendida. Vários autores têm descrito o efeito de drogas na marcação de elementos sanguíneos com tecnécio-99m (99mTc)e na biodistribuição de radiofármacos. Quando a IDR é conhecida, se desejada ou indesejada, a conseqüência natural é um diagnóstico correto. Quando a IDR é desconhecida, ela é indesejada e as conseqüências são a possibilidade de diagnóstico impreciso e/ou a repetição do exame com um aumento de dose de radiação para o paciente. As possíveis explicações para o aparecimento da IDR são (a) modificação do radiofármaco, (b) alteração da eficiência de marcação do radiofármaco, (c) modificação do alvo, (d) modificação do não alvo e/ou (e) alteração da ligação do radiofármaco aos elementos sanguíneos. O efeito de drogas na marcação de elementos sanguíneos com $99 \mathrm{mTc}$ poderia ser explicado por (i) uma direta inibição (ação quelante) dos íons estanoso e pertecnetato, (ii) danos na membrana eritrocitária, (iii) competição dos referidos íons pelos mesmos sítios de ligação, (iv) possível geração de espécies reativas de oxigênio e/ou direta oxidação do íon estanoso. Em conclusão, o desenvolvimento de modelos biológicos para o estudo da IDR é altamente relevante.

\section{REFERENCES}

Bernardo-Filho, M.; Caniné, M. S.; Lopes, R. L. F. and Boasquevisque E. M. (1986), Effect of temperature on the "in vitro" labeling of red blood cells with technetium-99m. Arq. Biol. Tecnol., 29, 407-412.

Bernardo-Filho, M.; Gutfilen, B. and Maciel, O. S. (1994), Effect of different anticoagulants on the labelling of red blood cells and plasma proteins with Tc-99m. Nucl. Med. Comm., 15, 730-734.

Bernardo-Filho, M.; Moura, I. N. S. and Boasquevisque E. M. (1983), Technetium-99m labeled red blood cells "in vitro". Arq. Biol. Tecnol., 26, 455-461.

Braga, A. C. S.; Oliveira, M. B. N.; Feliciano, G. D.; Reiniger, I. W.; Oliveira, J. F.; Silva, C. R. and Bernardo-Filho, M. (2000), The effect of drugs on the labeling of blood elements with technetium-99m. Curr. Pharm. Design, 6, 1179-1191.

Britto, D. M. M.; Gomes, M. L.; Rodrigues, P. C.; Paula, E. F.; Gutfilen, B. and Bernardo-Filho, M. (1998), Effect of the chemotherapeutic drugs on the biodistribution of ${ }^{99 \mathrm{~m}} \mathrm{Tc}-\mathrm{DTPA}$ in Balb/c mice. $J$. Exp. Clin. Cancer Res., 17, 313-316.

Callahan, R. J. and Rabito, C. A. (1990), Radiolabeling of erythrocytes with technetium-99m: role of band-3 protein in the transport of pertechnetate across the cell membrane. J. Nucl. Med., 31, 2004-2008.

Carlsson, S. (1995), A glance at the history of nuclear medicine. Acta. Oncol., 34, 1095-1102.

Chandra, R. (1998), Nuclear Medicine Physics the Basics $5^{\text {th }}$ edition. New York: Williams \& Wilkins.

Chen, W. L.; Perng, M. Y.; Hwei, D. Z. and Yu, M. D. (1994), Therapeutic drug monitoring can avoid iatrogenic alterations caused by ${ }^{99 \mathrm{~m}} \mathrm{Tc}-\mathrm{methylene}$ diphosphonate (MDP)-gentamicin interaction. J. Nucl. Biol. Med., 38 : (4 Suppl. 1), 132-134.

Diré, G.; Lima, E.; Mattos, D.; Oliveira, M. B.; Pereira, M. J.; Moreno, S.; Freitas, R.; Gomes, M. L. and Bernardo-Filho, M. (2001), Effect of chayotte (Sechium edule) extract on the biodistribution of technetium-99m and on the morphometry of red blood cells. J. Label. Compds. Radiophars., 44, S648-S650.

Early, P. J. and Sodee, D. B. (1996), Principles and Practice of Nuclear Medicine. Toronto: Mosby - Year Book Inc. 
Eising, E. G. and Sciuk, J. (1995), Failure to label red blood cells adequately in daily practice using an in vivo method: methodological and clinical considerations. Eur. J. Nucl. Med., 22 : (6), 587.

Gomes, M. L.; Braga, A. C.; Mattos, D. M.; Freitas, R. S.; Paula, E. F.; Bezerra, R. J. A. C. and BernardoFilho, M. (2002), Effect of the mitomycin-C on the biodistribution of the radiopharmaceutical 99mTechnetium-phytic acid in mice: a model to evaluate the toxic effect of a chemical drug. J. Appl. Toxicol., 22, 85-87.

Gomes, M. L.; Braga, A. C. S.; Mattos, D. M. M.; Freitas, R. S.; Boasquevisque, E. M. and BernardoFilho, M. (1998), Mitomycin-C effect on the biodistribution of the radiopharmaceutical technetium-99m-methylenediphosphonic acid in balb/c mice. Nucl. Med. Commun., 19, 1177-1179.

Gomes, M. L.; Mattos, D. M. M.; Freitas, R. S.; Bezerra, J. R. A. C. and Bernardo-Filho, M. (2001), Study of the toxicological effect of mitomycin $\mathrm{C}$ in mice: alteration on the biodistribution of radiopharmaceuticals used for renal evaluations. Hum. Exp. Toxicol., 20, 193-197.

Harbert, J. C.; Eckelman, W. C. and Neumann, R. D. (1996), Nuclear Medicine Diagnosis and therapy. Thieme Medical Publishers, New York.

Hesslewood, S. and Leung, E. (1994), Drug interactions with radiopharmaceuticals. Eur. J. Nucl. Med., 21, 348-356.

Hladik III, W. B.; Nigg, K. K. E. and Rhodes, B. A. (1982), Drug-induced changes in the biologic distribution of radiopharmaceuticals, Semin. Nucl. Med., 9,184-192.

Hladik III, W. B.; Saha, G. B. and Study, K. T. (1987), Essentials of Nuclear Medicine Science. William and Wilkins, London.

Hojelse, C.; Kristensen, K. and Sampson, C. B. (1994), In: Sampson CB ed. Textbook of Radiopharmacy Theory and Practice. London.

Hung, G. L.; James, A. P. and Hammes, R. J. (1996), Radiopharmaceuticals related pitfalls and artifacts. Semin. Nucl. Med., 26, 208-255.

Lee, H. B.; Wexler, J. P.; Scharf, S. C. and Blaufox, M. D. (1983), Pharmacologic alterations in Tc-99m binding by red blood cells: concise communication. $J$. Nucl. Med., 24 : (5), 397-401.

Lima, E. A. C.; Diré, G.; Mattos, D. M. M.; Freitas, R.; Gomes, M. L.; Oliveira, M. B.; Faria, M. V. C.; Jales, R. L. and Bernardo-Filho, M. (2002), Effect of an extract of cauliflower (leaf) on the labeling of blood elements with technetium-99m and on the survival of Escherichia coli AB1157 submitted to the treatment with stannous chloride. Food Chem. Toxicol., 40, 919-923.
Mattos, D. M. M.; Gomes, M. L.; Freitas, R. S. and Bernardo-Filho, M. (1999), Effect of the chemotherapeutic drugs on the biodistribution of the radiopharmaceutical ${ }^{99 \mathrm{~m}}$ Tc-phytate in Balb/c mice. In-: Nicolini, M. and Mazzi, U. (eds.) Technetium, Rhenium and Other Metals in Chemistry and Nuclear Medicine. Podova: Servizi Grafici Editoriali. pp. 465-472.

Mattos, D. M. M.; Gomes, M. L.; Freitas, R. S.; Cardoso, V. N. and Bernardo-Filho, M. (2001), Drug interaction with radiopharmaceuticals and the importance for the radiation dose to the patient. In: IAEA (eds.) Radiological protection of patients in diagnostic and interventional radiology, nuclear medicine and radiotherapy. Vienna, Austria.

Mattos, D. M. M.; Gomes, M. L.; Freitas, R. S.; Rodrigues, P. C.; Paula, E. F. and Bernardo-Filho, M. (1999), A model to evaluate the biological effect of natural products: vincristine action on the biodistribution of radiopharmaceuticals in Balb/c female mice. J. Appl. Toxicol., 19, 251-254.

Moreno, S. R. F.; Feliciano, G. D.; Freitas, R. S.; Mattos, D. M.; Gomes, M. L.; Farah, M. B.; Laurentino-Filho, G.; Rocha, E. K. and BernardoFilho, M. (2001), Effect of Ginkgo biloba on the in vitro labeling of red blood cells and plasma proteins with technetium-99m. J. Label. Compd. and Radioph., 44, S639-S641.

Oliveira, J. F.; Braga, A. C. S.; Ávila, A. S.; Fonseca, L. M. B.; Gutfilen, B. and Bernardo-Filho, M.( 1996), Effect of Thyua occidentalis on the labeling of red blood cells and plasma proteins with technetium99m. Yale J. of Biol. Med., 69, 489-494.

Oliveira, J. F.; Braga, A. C. S.; Oliveira, M. B. N.; Ávila, A. S.; Caldeira-de-Araújo, A.; Nascimento, C. V.; Bezerra, R. J.and Bernardo-Filho, M. (2000), Effect of Maytenus ilicifolia (espinheira santa) extract on the labeling of red blood cells and plasma proteins with technetium-99m. J. Ethnopharmacol., 72, 179-184

Oliveira, J. F.; Avila, A. S.; Braga, A. C. S.; Oliveira, M. B. N.; Boasquevisque, E. M.; Jales, R. L.; Cardoso, V. N. and Bernardo-Filho, M. (2002), Effect of extract of medicinal plants on the labeling of blood elements with technetium-99m and on the morphology of red blood cells: I - a study with Paullinia cupana. Fitoterapia, 73, 305-312.

Owunwanne, A.; Patel, M. and Sadek, S. (1995), Preparation of radiopharmaceuticals. The handbook of radiopharmaceuticals. London: Chapman \& Hall.

Owunwanne, A.; Shihab-Eldeen, A.; Yacoub, T. and Ziada, G. (1998), The use of radiopharmaceuticals as an effective toxicologic technique for studying nephrotoxicity of drugs: cyclosporine-A. Hum. Exp. Toxicol., 17, 613-619. 
Passos, M. C. F.; Ramos, C. F.; Bernardo-Filho, M.; Mattos, D. M. and Moura, E. G. (2000), The effect of protein or energy restriction on the biodistribution of $\mathrm{Na}^{99 \mathrm{~m}} \mathrm{TcO}_{4}$ in Wistar rats. Nucl Med Comm, 21, 10591062.

Passos, M. C. F.; Ramos, C. F.; Dutra, S. C. P.; Bernardo-Filho, M. and Moura, E.G. (2002), Biodistribution of $\mathrm{Na}^{99 \mathrm{~m}} \mathrm{TcO}_{4}$ changes in adult rats whose mothers were malnourished during lactation. $J$. Nucl. Med.2 43, 89-91.

Perkins, A. and Frier, M. (1999), Nuclear Medicine in Pharmaceutical Research. Taylor \& Francis, London.

Reineger, I. W.; Oliveira, J. F.; Caldeira-de-Araújo, A. and Bernardo-Filho, M. (1999), Effect of Peumus boldus on the labeling of red blood cells and plasma proteins with technetium-99m. App. Radiat. Isot., 51, 145-149.

Saha, G. B. (1998), Fundamentals of Nuclear Pharmacy. New York: Springer-Verlag.

Sampson, C. B. (1993), Adverse reactions and drug interactions with radiopharmaceuticals. Drug Safety., 8, 280-294.

Sampson, C. B. (1996), Complications and difficulties in radiolabelling blood cells: A review. Nucl. Med. Comm., 17, 648-658.

Santos, J. S.; Paula, E. F.; Correa, T. G.; Freitas, L. C.; Fonseca, L. M.; Gutfilen, B. and Bernardo-Filho, M. (1995), Effect of cyclophosphamide on the binding of $99 \mathrm{mTcO}_{4}^{-}$and $99 \mathrm{mTc}-\mathrm{MDP}$ to blood cells and plasma proteins. Braz. J. Med. Biol. Res., 28, 131-135.
Spicer, J. A.; Hladik, W. B. and Mulberry, W. E. (1999), The effects of selected antineoplastic agents on the labeling of erythrocytes with technetium-99m using the UltraTag RBC kit. J. Nucl. Med. Technol., 27, 132-135.

Srivastava, S. C.; Straub, R. F. and Richards, P. (1984), Mechanistic aspects of the technetium-99m-tin-RBC labeling reactions. J. Label. Comp. Radioph., 21, 1055.

Tatum, J. L.; Burke, T. S.; Hirsch, J. I.; Miller, W. W. and Fratkin, M. J. (1983), Pitfall to modified in vivo method of technetium-99m red blood cell labeling. Iodinated contrast media. Clin. Nucl. Med., 8, 585-587.

Vento, J. A.; Swing, L. S. and Spencer, R. P. (2000), Persistent binding of Tc-99m pertechnetate to erythrocytes in a patient receiving multiple pharmaceuticals. Clin. Nucl. Med., 25,152-153.

Vidal, M. V.; Gutfilen, B.; Barbosa-da-Fonseca, L. M. and Bernardo-Filho, M. (1998), Influence of tobacco on the labeling of red blood cells and plasma proteins with technetium-99m. J. Exp. Clin. Cancer Res., 17, $1-6$. 